\title{
Choose or lose, another road to China's sustainable development
}

Citation for published version (APA):

Lu, M. (2017). Choose or lose, another road to China's sustainable development: A law and economics analysis of corporate sustainability theories and practices. [Doctoral Thesis, Maastricht University]. Datawyse / Universitaire Pers Maastricht. https://doi.org/10.26481/dis.20170918ml

Document status and date:

Published: 01/01/2017

DOI:

10.26481/dis.20170918ml

Document Version:

Publisher's PDF, also known as Version of record

\section{Please check the document version of this publication:}

- A submitted manuscript is the version of the article upon submission and before peer-review. There can be important differences between the submitted version and the official published version of record.

People interested in the research are advised to contact the author for the final version of the publication, or visit the DOI to the publisher's website.

- The final author version and the galley proof are versions of the publication after peer review.

- The final published version features the final layout of the paper including the volume, issue and page numbers.

Link to publication

\footnotetext{
General rights rights.

- You may freely distribute the URL identifying the publication in the public portal. please follow below link for the End User Agreement:

www.umlib.nl/taverne-license

Take down policy

If you believe that this document breaches copyright please contact us at:

repository@maastrichtuniversity.nl

providing details and we will investigate your claim.
}

Copyright and moral rights for the publications made accessible in the public portal are retained by the authors and/or other copyright owners and it is a condition of accessing publications that users recognise and abide by the legal requirements associated with these

- Users may download and print one copy of any publication from the public portal for the purpose of private study or research.

- You may not further distribute the material or use it for any profit-making activity or commercial gain

If the publication is distributed under the terms of Article $25 \mathrm{fa}$ of the Dutch Copyright Act, indicated by the "Taverne" license above, 


\title{
Propositions relating to the dissertation
}

\author{
"CHOOSE or LOSE, another road to China's sustainable development: \\ A law and economics analysis of corporate sustainable theories and practices"
}

\section{Mengxing Lu}

1. Due to an ongoing series of corporate scandals, showing a broad spectrum of irresponsible business behavior, the corporate community does face increasing public distrust, criticism and protest. In order to regain this essential public trust, corporations need to really internalize their social and environmental responsibilities (CSR/CER) and to adjust their corporate policies and activities correspondingly.

2. Various, broadly accepted, international codes of corporate social and environmental responsibilities (CSR/CER) do provide a wide spectrum of specific actions which contribute to sustainable development, and vast implementation of these codes throughout the business community and into the corporate activities will align corporate performance with this fundamental societal need.

3. Corporate social and environmental responsibility (CSR/CER) is often defined as: "going beyond mere compliance with mandatory social and environmental standards on a voluntary basis". However, as a form of voluntary self-regulation CSR/CER proves to lead also to new problems like "a market for lemons" or to a specific "principal-agent problem", and these problems undermine the trustworthiness of the CSR/CER approach and need to be firmly addressed.

4. The law and economics approach provides insights into the "strategic CSR/CER hypothesis", which indicates that CSR/CER creates substantial added value and hence becomes a source of increased competitiveness. More firmly and consistently addressing these CSR/CER related added values will have a profound positive effect on the eagerness to get CSR/CER implemented throughout the business community.

5. There is a trend of introducing more "hard law" and "soft law" regulation to provoke increased compliance with corporate social and environmental responsibilities (CSR/CER), and some of these approaches at the international and national level do show positive effects and deserve global support.

6. Given the complicated nature of environmental dimensions, aspects and issues, there is a smart mix needed of government regulation and private initiatives in order to substantially improve environmental performance of companies and states.

7. Ensuring compliance with regulation should be the number one priority of China's environmental protection and sustainable development policies.

8. Writing a PhD requires "a will to win, a desire to succeed and an urge to reach your full potential...", which is fully in line with Confucius' view on reaching personal excellence and provide the key to unlock the door to it.

9. A foreign PhD candidate encounters various substantial challenges in values, culture and language during their research and writing process. The more effective the policies are in order to fully integrate these candidates into the university/faculty, the better the candidates will be able to overcome these challenges and to realize the highest quality of their research and thesis. 